KS. ZBIGNIEW JANCZEWSKI

Wydział Prawa Kanonicznego

Uniwersytetu Kardynała Stefana Wyszyńskiego w Warszawie

\title{
KONIECZNOŚĆ (NECESSITAS) \\ JAKO KATEGORIA KANONICZNA \\ W PRAWIE O SAKRAMENTACH \\ WTAJEMNICZENIA CHRZEŚCIJAŃSKIEGO \\ I UZDROWIENIA W KODEKSIE Z 1983 R.
}

Treść: Wstęp. - 1. Normy wprowadzające do sakramentów i dotyczące bierzmowania. - 2. Chrzest. - 3. Eucharystia. - 4. Sakramenty uzdrowienia. - 5. Necessitas jako kategoria kanoniczna - synteza problemu. - Zakończenie.

\section{Wstęp}

Sprawowanie sakramentów świętych to obok głoszenia Słowa Bożego, jedno z głównych zadań, stawianych przez Kościół kapłanom. Celebracja nie jest uzależniona od subiektywnej woli szafarzy i osób przyjmujących. Ustalanie obiektywnych kryteriów dotyczących omawianej kwestii, zostało bowiem powierzone przez Chrystusa Kościołowi. Warunki, których zachowanie jest wymagane przy sprawowaniu sakramentów, określone są w Kodeksie prawa kanonicznego i księgach liturgicznych. Jeden z nich stanowi konieczność - necessitas.

Przedmiotem badań, których wyniki zostały opublikowane w niniejszym artykule są sakramenty wtajemniczenia chrześcijańskiego i uzdrowienia, czyli chrzest, bierzmowanie, Eucharystia, pokuta i namaszczenie chorych, $\mathrm{w}$ aspekcie dopuszczalności ich sprawowania, ze względu na zachowanie wspomnianego już warunku konieczności. Poza polem zainteresowań znalazły się natomiast sakramenty społeczne, czyli święcenia, przy których kategoria konieczności nie występuje w kodeksie oraz małżeństwo, którym kanoniści zajmują 
się zazwyczaj w osobnych publikacjach. Materiał badawczy został podzielony na pięć części. W pierwszej dokonano analizy kodeksowych norm dotyczących wprowadzenia do sakramentów oraz bierzmowania. Kolejne dotyczą chrztu, Eucharystii i sakramentów uzdrowienia. Ostatni z punktów obejmuje syntezę problemów związanych z warunkiem konieczności, dokonaną na podstawie wcześniej analizowanych norm.

\section{Normy wprowadzające do sakramentów i dotyczące bierzmowania}

Na początku księgi IV Kodeksu prawa kanonicznego, dotyczącej posługi uświęcania znalazły się normy wprowadzające do sakramentów. Dotyczą one między innymi problemu udzielania ich chrześcijanom nienależącym do Kościoła katolickiego oraz przyjmowania przez katolików od szafarzy niekatolickich. Dotyczą Eucharystii, pokuty i namaszczenia chorych. Jedna z norm stanowi, że ilekroć domaga się tego konieczność, albo zaleca prawdziwy pożytek duchowy i nie zachodzi niebezpieczeństwo błędu albo indyferentyzmu, wolno wiernym, dla których fizycznie lub moralnie jest niemożliwe udanie się do szafarza katolickiego, przyjąć wspomniane sakramenty od szafarzy Kościoła, w którym są one ważnie sprawowane ${ }^{1}$. Według Pighina, taką koniecznością jest sytuacja szczególna, kiedy to wierny znalazł się w niebezpieczeństwie śmierci i pragnie się wyspowiadać, przyjąć Wiatyk i namaszczenie chorych ${ }^{2}$. Chodzi zatem o sakramenty, których wiernemu katolikowi brakowałoby dla jego życia duchowego i życia w łasce. Inny kanonista - Trevisan słusznie zauważa, iż konieczności nie weryfikuje wyłącznie niebezpieczeństwo śmierci, stanowi go również niezaspokojenie przez dłuższy czas duchowej potrzeby przyjęcia sakramentów, szczególnie Eucharystii'. Egzemplifikacją wspomnianej necessitas mogą być sytuacje, kiedy wierny znajduje

\footnotetext{
${ }^{1}$ Kan. 844 par. 2.

${ }^{2}$ B. F. Pighin, Diritto sacramentale, Venezia 2006, s. 89.

${ }^{3}$ G. Trevisan, I sacramento, w: Codice di Diritto Canonico commentato. A cura della Redazione di Quaderni di diritto ecclesiale, Milano 2009, s. 719-720.
} 
się $\mathrm{w}$ rejonie, $\mathrm{w}$ którym nie ma duszpasterzy katolickich, albo też z różnych przyczyn, np. politycznych nie mogą oni wykonywać swoich obowiązków i odczuwa potrzebę przyjęcia Najświętszego Sakramentu, pokuty, albo namaszczenia chorych. Oczywiście należy przestrzegać pozostałych warunków przewidzianych przez cytowaną normę.

Ocenę, czy zachodzą takowe warunki, w tym czy mamy do czynienia $\mathrm{z}$ koniecznością, prawodawca kościelny pozostawił zainteresowanym sakramentem wiernym ${ }^{4}$. Przyjęcie sakramentów poza przypadkiem konieczności, albo kiedy nie zaleca tego prawdziwy pożytek duchowy, chociażby ze względu na „niewyróżnianie się w tłumie" uczestników biorących udział w nabożeństwie jakiegoś Kościoła chrześcijańskiego, nie skutkuje nieważnością takiej czynności, jest jednak bezprawne i noszące znamię niegodziwości moralnej.

Paragraf 4 cytowanego kanonu zezwala na udzielanie wcześniej wspomnianych sakramentów przez szafarzy katolickich chrześcijanom nienależącym do niekatolickich Kościołów wschodnich, którzy nie mogą udać się do szafarzy swojej wspólnoty i sami o nie proszą, jeżeli w odniesieniu do tych sakramentów wyrażają wiarę katolicką i do ich przyjęcia są odpowiednio przygotowani. Warunkiem jest wystąpienie niebezpieczeństwa śmierci, albo też, co nas interesuje najbardziej, inna poważna konieczność, uznana przez biskupa diecezjalnego, albo Konferencję Biskupów ${ }^{5}$. W przypadku tej normy ocena, czy ma się do czynienia z poważną koniecznością nie należy już do proszącego o sakrament. Można domniemywać, że prawodawca kościelny nie darzy tak wielkim zaufaniem z jakim odnosi się do katolików, wyznawców innych religii chrześcijańskich, w których często, na fali źle pojmowanego ekumenizmu, panuje swego rodzaju indyferentyzm religijny.

Takowa ocena nie została również pozostawiona szafarzowi, a tylko biskupom diecezjalnym i Konferencjom Biskupów. Konferencja Episkopatu Włoch wśród przypadków konieczności wymienia

\footnotetext{
${ }^{4}$ P. Hemperek, Uświęcające zadanie Kościoła, w: Komentarz do Kodeksu prawa kanonicznego, t. 3, Lublin 1986, s. 69.

${ }^{5}$ Kan. 844 par. 4.
} 
chrześcijan w stanie chorobowym, uchodźców, więźniów, prześladowanych, a także pojawienie się trudności moralnej w otrzymaniu sakramentu od własnego szafarza ${ }^{6}$.

Kiedy poza omówionymi dwoma sytuacjami, zawartymi we wprowadzeniu do prawa o sakramentach, prawodawca uzależnił ich sprawowanie od wystąpienia konieczności? Z jednym takim przypadkiem spotykamy się w kanonach dotyczących bierzmowania. Biskup diecezjalny powinien udzielać bierzmowania osobiście, albo zatroszczyć się o to, aby uczynił to inny biskup. Natomiast, jeśli domaga się tego konieczność, może jednemu lub kilku określonym prezbiterom, udzielić upoważnienia do sprawowania sakramentu? ${ }^{7}$. Frank wśród przypadków takowej konieczności wylicza przykładowo chorobę biskupa, albo sytuację, w której jego pieczy duszpasterskiej została powierzona taka ilość parafii, że sam nie jest w stanie w każdej z nich bierzmować $\mathrm{w}$ odpowiednim czasie ${ }^{8}$. Innym przypadkiem będzie duża liczba przystępujących do sakramentu, powodująca poważne przeciągniecie się ceremonii w czasie ${ }^{9}$. Czy konieczność determinuje ważność udzielenia takiego upoważnienia prezbiterowi? Wydaje się że tak nie jest, w przeciwnym bowiem razie, gdyby ocena sytuacji przez biskupa byłaby niewłaściwa, wierni bez własnej winy, nie wiedząc o tym, podczas ceremonii sprawowanej przez wyznaczonego bezprawnie prezbitera, nie otrzymaliby bierzmowania.

\section{Chrzest}

W partii Kodeksu prawa kanonicznego dotyczącej sakramentu chrztu, znajdujemy kilka norm, w których prawodawca kościelny uzależnia pewne czynności od wystąpienia necessitatis. Poza przypadkiem konieczności, woda używana przy udzielaniu chrztu ma być

\footnotetext{
${ }^{6}$ G. Trevisan, dz. cyt., s. 721.

${ }^{7}$ Kan. 884 par. 1.

${ }^{8}$ E. Frank, I Sacramenti dell'Iniziazione, della Penitenza e dell'Unzione degli infermi. Commento ai Canoni 834-1007 del Codice di Diritto Canonico, Città del Vaticano 2012, s. 84.

${ }^{9}$ G. Trevisan, dz. cyt., s. 748.
} 
poświęcona zgodnie z przepisami ksiąg liturgicznych. ${ }^{10}$ Zasadniczo dokonuje się tego w czasie ceremonii Wigilii Wielkanocy. W miarę możliwości powinno się ją zachowywać przez cały okres wielkanocny, używając w tym czasie do chrztu, co stanowi podkreślenie łączności tego sakramentu z tajemnicą paschalną. Poza wspomnianym okresem zaleca się poświęcać wodę przy każdorazowym udzielaniu chrztu. Używanie wody poświęconej nie jest bynajmniej wymagane do ważności chrztu. Stąd też w przypadku konieczności możliwe jest zastosowanie wody niepoświęconej ${ }^{11}$. We wspomnianej sytuacji jest to jak najbardziej godziwe i dopuszczalne. Konieczność może pojawić się, kiedy sakrament jest sprawowany w niebezpieczeństwie śmierci, poza świątynią, a nawet w świątyni, kiedy szafarzem z braku obecności kapłana staje się osoba świecka, nie mająca do dyspozycji święconej wody. Gdy chrztu udziela kapłan, praktycznie w każdej sytuacji może poświęcić wodę. Z tego też powodu, jak się wydaje, warunek konieczności jest spełniony, gdy funkcję szafarza pełni osoba nieposiadająca święceń. Kwestia ta (brak wyświęconego szafarza i brak wody poświęconej) determinuje decyzję o wystąpieniu przypadku konieczności.

Omawianego sakramentu udziela się w kościele lub kaplicy. W innym miejscu można to uczynić w przypadku konieczności ${ }^{12}$. Taką sytuacją, przewidzianą przez obrzędy chrztu, jest niebezpieczeństwo śmierci, w którym znalazł się katechumen ${ }^{13}$. Przy chrzcie dorosłego przypadek konieczności może mieć miejsce, kiedy fakt ten musi zostać utrzymany w tajemnicy ${ }^{14}$. Natomiast nie można mówić o konieczności, jeżeli chrztu udziela się w domu prywatnym ze względu na pozycję społeczną lub ekonomiczną osób zainteresowanych, albo

\footnotetext{
${ }^{10}$ Kan. 853.

${ }^{11}$ P. Hemperek, dz. cyt., s. 81.

${ }^{12}$ Kan. 857 par. 1.

${ }^{13}$ Rituale Romanum, ex Decreto Sacrosancti Oecumenii Concilii Vaticani II instauratum, Auctoritate Pauli PP. VI promulgatum, Ordo Baptismi Parvulorum, Editio typica. Typis Polyglottis Vaticanis 1969, n. 12, p. 18.

${ }^{14}$ M. Pastuszko, Prawo o sakramentach świętych. Normy ogólne i sakrament chrztu, t.1, Warszawa 1983, s. 326.
} 
w jakimś niecodziennym miejscu, np. w rzece, z chęci wyróżnienia się od innych. Budynki sakralne są bowiem od wieków miejscem sprawowania sakramentów i w nich znajdujemy najbardziej ku temu sprzyjające warunki. O tym czy dane okoliczności wyczerpują znamiona konieczności, decyduje szafarz chrztu.

Niejako uzupełnieniem omawianego kanonu jest norma stanowiąca, że poza przypadkiem konieczności, chrztu nie można udzielać $\mathrm{w}$ domach prywatnych chyba, że ordynariusz miejsca zezwoli na to z poważnej przyczyny. Konieczność, albo inna racja duszpasterska, o ile biskup diecezjalny nie zarządzi inaczej, uzasadnia udzielanie sakramentu w szpitalach ${ }^{15}$. Należy zauważyć, iż prawodawca rozróżnia tutaj przypadek konieczności od poważnej przyczyny. Druga z wymienionych upoważnia biskupa do wydania zezwolenia na chrzest w domu prywatnym. Pierwsza, nas interesująca szczególnie, stanowi uzasadnienie dla szafarza, aby ochrzcił $\mathrm{w}$ domu bez zezwolenia biskupa diecezjalnego. Z koniecznością (oprócz innej racji duszpasterskiej), mamy również do czynienia dla uzasadnienia chrztu w budynku szpitalnym.

Według Krzywdy koniecznością chrztu poza świątynią, w domu mieszkalnym jest zagubienie kluczy do kościoła przed ceremonią, śmiertelna choroba dziecka, lub ogólnie słaby jego stan zdrowia po ciężkim porodzie. Zakaz chrztu w domach prywatnych, czy szpitalach, w których dzieci przychodzą na świat, jest zasadniczo uzasadniony tym, aby różnorodne okoliczności nie stawały się pretekstem do sprawowania chrztu w miejscach do tego nieprzeznaczonych ${ }^{16}$.

Poza przypadkiem konieczności, bez zezwolenia, nie wolno udzielać chrztu na obcym terytorium, nawet własnym podwładnym ${ }^{17}$. Przypadek konieczności legitymizuje więc godziwość sprawowania sakramentu na obcym terytorium przez duszpasterza. Zakaz ten należy widzieć w optyce faktu, iż miejscem preferowanym dla

\footnotetext{
${ }^{15}$ Kan. 860.

${ }^{16}$ J. KRZYwDA, Sakramenty, w: Komentarz do Kodeksu prawa kanonicznego.

Księga IV. Uświęcające zadanie Kościoła, t. III/2, Poznań 2011, s. 47.

${ }^{17}$ Kan. 862.
} 
przyjęcia interesującego nas sakramentu jest własna parafia kandydata, dzięki której otwiera się dla niego i go przyjmuje wspólnota Kościoła. Człowiek przez chrzest nie tylko staje się członkiem Kościoła, lecz ponadto cząstką konkretnej wspólnoty parafialnej ${ }^{18}$. Stąd jedynie przypadek konieczności, zweryfikowany przez wydanie zezwolenia (pisemnego albo ustnego) przez duszpasterza, któremu podlega terytorium, na którym ma się odbyć chrzest, uzasadnia jego udzielenie przez szafarza znajdującego się poza miejscem swojej pieczy duszpasterskiej. Dotyczy to nawet własnego parafianina.

W przypadku cytowanej normy pojawia się jednak wątpliwość. Jak wyobrazić sobie konkretne przypadki konieczności, w kontekście wymogu otrzymania zezwolenia. Kapłan chcący ochrzcić dziecko znajomych, mieszkających poza jego parafią, może prosić o wymagane zezwolenie, ale czy $\mathrm{w}$ takiej sytuacji mamy do czynienia z koniecznością? Nie koniecznie przecież sakramentu musi udzielić właśnie on. A chrzest w sanktuarium, przy okazji odbywanej tam pielgrzymki..., czy można mówić o konieczności ochrzczenia kogoś właśnie tam? Natomiast z pewnością, z przypadkiem konieczności będziemy mieli do czynienia, kiedy miejscowy duszpasterz nagle zachoruje, a przebywający w jego parafii gościnnie kapłan, zaoferuje swoją pomoc w sprawowaniu sakramentu.

\section{Eucharystia}

Warunek pojawienia się konieczności znajdujemy również w normach kodeksowych dotyczących Eucharystii. Kiedy brakuje kapłanów, ordynariusz miejsca może zezwolić, o ile domaga się tego konieczność duszpasterska, na trynację w niedziele i święta nakazane ${ }^{19}$. Jak zauważa Pastuszko chodzi tutaj o brak kapłana diecezjalnego czy zakonnego, mogącego sprawować Mszę św. dla wiernych w odpowiednim miejscu i czasie. Jeżeli jest on obecny fizycznie w parafii, ale nie może sprawować Mszy, bo przykładowo zachorował, lub też nie chce zgodzić się na celebrowanie z jemu wiadomych powodów,

\footnotetext{
${ }^{18}$ E. Frank, dz. cyt., s. 41.

${ }^{19}$ Kan. 905 par. 2.
} 
wtedy mamy do czynienia z przewidzianym przez cytowaną normę brakiem $^{20}$.

Drugim, bardziej interesującym nas warunkiem jest konieczność duszpasterska. To coś więcej niż słuszna przyczyna, wymagana dla binacji. Konieczność ma miejsce, kiedy znaczna część wiernych, to jest nie mniej niż dziesięć osób, nie weźmie udziału we Mszy bez jej trynowania przez kapłana ${ }^{21}$. Przyczyną wystąpienia konieczności z pewnością nie jest motyw podkreślenia wagi uroczystości, która gromadzi kapłanów przy ołtarzu ${ }^{22}$. Podobnie w przypadku motywu osobistej dewocji oraz usatysfakcjonowania wiernych, którzy w danym dniu domagają się odprawienia Mszy w wyznaczonej przez nich intencji ${ }^{23}$. Wydaje się, że podana przez Pastuszkę definicja konieczności duszpasterskiej, czyli kiedy znaczna część wiernych nie będzie miała możliwości uczestniczenia w Eucharystii niedzielnej lub świątecznej jest właściwa. Wątpliwość budzi jedynie podawana przez niego liczba - minimum dziesięć osób. Czy dla pięciu osób duszpasterz nie mógłby już trynować, pozostawiając ich bez tak ważnej łaski duchowej, jaką otrzymuje się przez uczestnictwo w Eucharystii w nakazany przez Kościół dzień?

Warunki, na jakich można uznać konkretny przypadek za konieczność określa ordynariusz miejsca. Może to czynić w odniesieniu do określonego przypadku, w którym duszpasterz poprosi o zezwolenie na trynowanie, albo wydając dla kapłanów swojej diecezji normę, w której interesujące nas warunki zostają wyszczególnione. W praktyce, chyba zbyt często prawodawstwo diecezjalne, dotyczące interesującej nas kwestii, nie zawiera tego istotnego elementu, ograniczając się jedynie do zacytowania kanonu, z przypomnieniem o wzięciu pod uwagę przez potencjalnie trynujących, konieczności duszpasterskiej.

\footnotetext{
${ }^{20}$ M. PAstuszko, Najświętsza Eucharystia według Kodeksu prawa kanonicznego Jana Pawła II, Kielce 1997, s. 88.

${ }^{21}$ Tamże, s. 93.

${ }^{22}$ G. Trevisan, L'Eucaristia, w: La funzione di santificare della Chiesa, Milano 1995, s. 107.

${ }^{23}$ G. Trevisan, I sacramento..., s. 760.
} 
Za Góreckim należy jeszcze przypomnieć, że trynacja poza niedzielą, może mieć miejsce także $\mathrm{w}$ święta nakazane prawem powszechnym, partykularnym lub zwyczajowym ${ }^{24}$.

Przypadek konieczności przewiduje także norma dotycząca udzielania Wiatyku, czyli Komunii św. osobom umierającym. Obowiązek i prawo zanoszenia go posiadają proboszcz i wikariusze parafialni, kapelani, przełożony wspólnoty w kleryckich instytutach zakonnych lub stowarzyszeniach życia apostolskiego, w odniesieniu do wszystkich przebywających w domach im podlegających, a ponadto in casu necessitatis, lub za przynajmniej domyślną zgodą proboszcza, kapelana lub wspomnianego wcześniej przełożonego, każdy kapłan lub szafarz Komunii św ${ }^{25}$. O konieczności można mówić, kiedy żadna z osób posiadających prawo i obowiązek udzielenia Wiatyku nie może tego uczynić, z powodu nieobecności lub wykonywania innych czynności duszpasterskich (np. w tym momencie celebruje Mszę św.).

Prawo do udzielenia Wiatyku, jak zauważa Pastuszko, łączy się z obowiązkiem jego przyjęcia. Ten drugi zachodzi wówczas, kiedy wierny znajdzie się w niebezpieczeństwie śmierci. Cytowany autor podaje jeszcze inne przyczyny wystąpienia konieczności: zły stan zdrowia, lub starość zobowiązanego do zaniesienia Komunii św. kapłana ${ }^{26}$.

O tym czy wystąpił przypadek konieczności decyduje osobiście kapłan lub świecki szafarz Eucharystii. Ma to miejsce w sytuacji, kiedy nie posiada nawet domyślnej zgody uprawnionych do udzielania Wiatyku.

Pozostawiając tę kwestę, przejdźmy teraz do sposobu przyjmowania Eucharystii przez wiernych. Należy Jej udzielać tylko pod postacią chleba, albo też zgodnie z przepisami liturgicznymi, pod obiema postaciami. Jednakże w przypadku konieczności, można

\footnotetext{
${ }^{24}$ E. Górecki, Eucharystia, w: Komentarz do Kodeksu prawa kanonicznego. Księga IV. Uświęcające zadanie Kościoła, t. III/2, Poznań 2011, s. 93.

${ }^{25}$ Kan. 911.

${ }^{26}$ M. PAstuszko, Najświętsza Eucharystia według Kodeksu prawa kanonicznego Jana Pawła II..., s. 132-133.
} 
wykomunikować wiernego tylko pod postacią wina ${ }^{27}$. Takie przypadki łączą się z chorobą przyjmującego Komunię, uniemożliwiającą uczynienie tego wraz z innymi osobami, które otrzymują Chleb Eucharystyczny ${ }^{28}$. Górecki podaje tutaj konkretne sytuacje:

- wierny nie może przyjmować pokarmów stałych,

- zabrakło komunikantów do udzielania Eucharystii w czasie Mszy św.,

- wierny choruje na celiakię i nie wolno mu spożywać chleba zawierającego gluten ${ }^{29}$.

Drugi w wymienionych przypadków wydaje się być niemożliwy do spełnienia w odniesieniu do osób świeckich uczestniczących we Mszy św., ponieważ w praktyce celebrujący Najświętszą Ofiarę przystępuje do komunikowania wiernych po wypiciu Krwi Pańskiej, kiedy kielich jest już pusty. Zdarza się natomiast podczas koncelebracji Mszy, że jej przewodniczący, przez pomyłkę spożyje całość konsekrowanego chleba, a w tabernakulum nie ma innych komunikantów. Wtedy koncelebransowi pozostaje jedynie wypicie Krwi Pańskiej. Decyzja dotycząca spełnienia warunku konieczności należy do celebrującego Mszę św., albo szafarza sakramentu udzielanego poza nią.

Dla uzupełnienia należałoby dodać, że Komunię św. w interesujący nas sposób podaje się przy użyciu specjalnej rurki, łyżeczki, albo też wprost $\mathrm{z}$ kielicha ${ }^{30}$.

Nawet w ostatecznej konieczności nie godzi się dokonywać konsekracji jednej postaci bez drugiej, albo obydwu poza Mszą św ${ }^{31}$. Konsekracja obu postaci, chleba i wina należy bowiem do istoty Eucharystii. Stąd konsekrowanie ich poza liturgią mszalną jest dokonywaniem istotnej zmiany w strukturze Najświętszej Ofiary ${ }^{32}$. $\mathrm{Z}$ twierdzeniem tym nie można się do końca zgodzić. Dokonanie

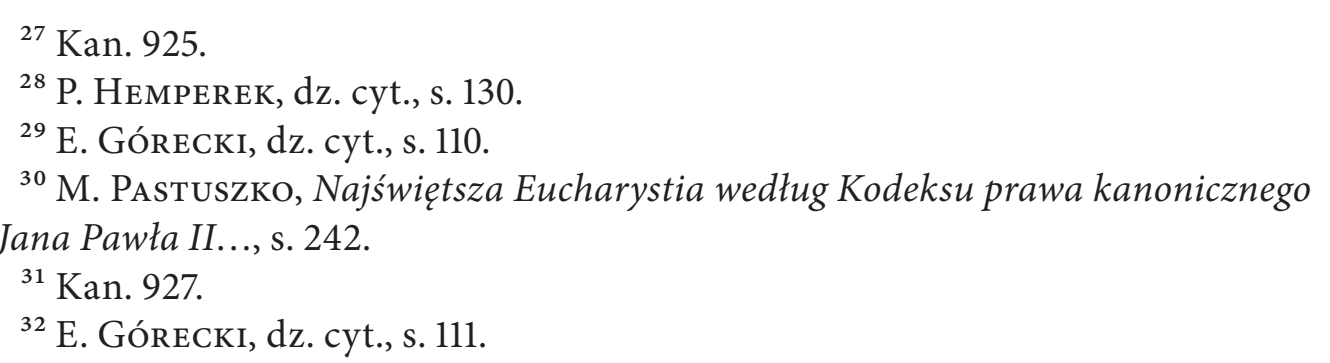


istotnej zmiany w strukturze skutkowałoby nieważnością takiego aktu. Prawodawca mówi jednak wyraźnie o niegodziwości takiego postępowania. Zdarzały się przypadki takiej świętokradczej konsekracji, w celu dokonania profanacji Eucharystii. O takiej profanacji nie można mówić w odniesieniu do zwykłego opłatka i wina.

Bezprawnym wydaje się być również konsekrowanie jednej postaci poza liturgią Mszy św., nawet gdy pojawi się ostateczna konieczność, czyli wierny poprosi o Komunię dla własnego pożytku duchowego, lub zostanie niejako zmuszony do tego przez znalezienie się w niebezpieczeństwie utraty życia. Tak rozumiana konieczność nie usprawiedliwia kapłana do zastosowania samych słów konsekracji, w celu przemienienia chleba w Eucharystię. Wydaje się jednak, iż uczynienie tego podczas Mszy, przed, albo nawet w trakcie udzielania Komunii św. wiernym, jeżeli zabraknie komunikantów, nie stanowi przypadku, którego dotyczy omawiana norma. Nie ma tu bowiem mowy o konsekracji jednej postaci bez drugiej, ale jednej po drugiej, czyli o kilka minut później, do tego, w czasie sprawowania Mszy św. Tym bardziej, że prawodawca kościelny zezwala $\mathrm{w}$ analogicznym przypadku, na osobną konsekrację wina. We wprowadzeniu do Mszału Rzymskiego czytamy: kiedy Kapłan przyjmując Komunię św. spostrzeże, iż przez pomyłkę w kielichu znalazła się sama woda z małą domieszką wina, powinien na nowo prawidłowo napełnić kielich winem, dolać kroplę wody i dokonać konsekracji, nie powtarzając słów konsekracyjnych chleba $^{33}$.

Reasumując trzeba stwierdzić, że nawet ostateczna konieczność, taka jak przykładowo niebezpieczeństwo poniesienia dotkliwych konsekwencji w razie odkrycia (w obozie koncentracyjnym), że kapłan celebruje Mszę św. i udziela Komunii, nie uzasadnia konsekrowania Eucharystii poza Mszą. Podobnie w ostatecznej konieczności, gdy np., w nadzwyczajnej sytuacji fizycznie brakuje wina albo chleba, nie wolno konsekrować podczas Mszy tylko jednej z postaci.

\footnotetext{
${ }^{33}$ Nowe Ogólne wprowadzenie do Mszału Rzymskiego, nr 324, Poznań 2004, s. 91; szerzej na temat ważności konsekracji w: Z. JANCzEwski, Materia i forma sakramentu Eucharystii, Prawo Kanoniczne 48(2005) nr 3-4, s. 45-49.
} 
Eucharystię należy celebrować w miejscu świętym, chyba że w poszczególnych przypadkach czego innego domaga się konieczność, wtedy możliwe jest jej sprawowanie w innym odpowiednim miej$\mathrm{scu}^{34}$. Rozpatrując ten przypadek necessitatis, należy zauważyć, że może ona występować zarówno po stronie kapłana, jak i wiernych. W przypadku tych drugich można przyjąć wystąpienie konieczności w niedziele i święta nakazane, w które istnieje obowiązek uczestniczenia we Mszy św. Ponadto należy celebrować poza miejscem świętym w związku z udzielaniem osobie umierającej Wiatyku. Rytuał Rzymski nakazuje bowiem, o ile to jest możliwe aby połączyć ze sobą Wiatyk i Mszę ${ }^{35}$, jednakże w takiej sytuacji trudno jest transportować umierającego do kościoła. $Z$ podobnym przykładem będziemy mieli do czynienia, kiedy ktoś z wiernych podróżujących z kapłanem po kraju gdzie trudno jest znaleźć świątynię katolicką, poprosi go o odprawienie Mszy w intencji właśnie zmarłej bliskiej osoby, albo jej powrotu do zdrowia po ulegnięciu poważnemu wypadkowi. Przykładowe sytuacje konieczności po stronie kapłana, to wcześniejsze przyjęcie przez niego zobowiązań mszalnych na dane dni, w które nie ma możliwości celebrowania w kościele. Chodzi tu głównie o tzw. Msze gregoriańskie ${ }^{36}$.

Kto podejmuje decyzję, czy rzeczywiście pojawił się przypadek konieczności? Zgodnie z prawem kodeksowym dokonywał tego sam celebrans. Norma ta jednak została zmodyfikowana przez Instrukcje Kongregacji Kultu Bożego i Dyscypliny Sakramentów Redemptionis sacramentum, wydaną 25 marca 2004 r. i zatwierdzoną przez papieża Jana Pawła II. Stanowi ona, iż każdorazowo, zgodnie ze zwyczajem diecezjalnym, decyzję podejmuje biskup diecezjalny ${ }^{37}$. Takie

\footnotetext{
${ }^{34}$ Kan. 932 par. 1.

${ }^{35}$ Por. Rituale Romanum ex Decreto Sacrosancti Consilii Vaticani II instauratum Auctoritate Pauli PP. VI promulgatum. Ordo Unctionis Infirmorum Eorumque Pastoralis Curae, nr 26, p. 8, Editio typica, Typis Polyglottis Vaticanis 1972.

${ }^{36}$ Z. Janczewski, Sprawowanie Eucharystii poza miejscem świętym, Prawo Kanoniczne 52(2009) nr 3-4, s. 298-300.

${ }^{37}$ Kongregacja Kultu Bożego i Dyscypliny Sakramentów, Instrukcja Redemptionis sacramentum, nr 108, Poznań 2004, s. 55.
} 
przeniesienie kompetencji podjęcia decyzji o konieczności odprawienia Mszy poza miejscem świętym, z jej celebransa na biskupa, zostało prawdopodobnie podyktowane częstym nadużywaniem przez kapłanów uprawnienia, które wcześniej nadawała im norma kodeksowa ${ }^{38}$.

Ostatni kanon dotyczący omawianej kwestii w odniesieniu do sakramentu Eucharystii stanowi, że nikomu nie wolno Jej przechowywać u siebie, ani też zabierać w drogę, chyba że nagli ku temu konieczność duszpasterska, z zachowaniem przepisów wydanych przez biskupa diecezjalnego ${ }^{39}$. Według Franka, takową koniecznością duszpasterską będzie brak możliwości przechowania Najświętszego Sakramentu w miejscu świętym i zagrożenie Jego profanacji. Ponadto wchodzą tutaj w grę motywy polityczne (zapewne autorowi chodzi o prawny zakaz przechowywania i adoracji, wydany przez wrogie Kościołowi władze państwowe), uszkodzenie lub zniszczenie świątyni oraz tym podobne ${ }^{40}$. Trevisan wymienia jeszcze bardziej szczegółowo inne sytuacje nadzwyczajne: powodzie, pożary, trzęsienia ziemi, wojny, na skutek których, ucierpiało miejsce święte ${ }^{41}$.

Biskup diecezjalny może wydać normy, bliżej precyzujące interesującą nas konieczność, w przypadku braku takowych o jej wystąpieniu musi zadecydować sam duszpasterz, sprawujący pieczę nad Eucharystią.

\section{Sakramenty uzdrowienia}

Do grupy sakramentów uzdrowienia należą pokuta i namaszczenie chorych. W odniesieniu do pierwszego z wymienionych, Kodeks prawa kanonicznego dwukrotnie uzależnia pewne działania od wystąpienia przypadku konieczności. Norma stanowi, że absolucja wielu penitentów równocześnie, bez uprzedniej indywidualnej spowiedzi może zostać udzielona poza niebezpieczeństwem śmierci, jeśli istnieje

\footnotetext{
${ }^{38}$ Z. JAnCzewski, Sprawowanie Eucharystii poza miejscem świętym..., s. 296.

${ }^{39}$ Kan. 935.

${ }^{40}$ E. Frank, dz. cyt., s. 131-132.

${ }^{41}$ G. Trevisan, I sacramento..., s. 779.
} 
poważna konieczność, czyli z uwagi na dużą liczbę penitentów, nie ma dostatecznej liczby spowiedników, do należytego wyspowiadania każdego z nich osobno w odpowiednim czasie, na skutek czego, penitenci bez własnej winy muszą pozostawać przez długi czas bez łaski sakramentalnej albo Komunii św. Za wymaganą konieczność nie jest uznawana sytuacja, kiedy brakuje wystarczającej liczby spowiedników jedynie z powodu wielkiego napływu penitentów, jaki może się zdarzyć podczas wielkiej uroczystości lub pielgrzymki. Wydawanie osądu, czy zachodzą warunki, spełniające przesłanki dla zastosowania absolucji generalnej, należy do biskupa diecezjalnego, który wziąwszy pod uwagę kryteria ustalone z pozostałymi członkami Konferencji Biskupów, może określić przypadek takiej konieczności ${ }^{42}$.

Należy zauważyć, że cytowana norma uzależnia wystąpienie poważnej konieczności od następujących przesłanek: duża liczba penitentów, zbyt mało spowiedników, penitenci bez wyspowiadania się indywidualnego przez dłuższy czas, nie ponosząc za to winy, pozostaną pozbawieni łaski sakramentu pokuty lub Komunii św. Kryterium negatywnym, czyli uznaniem niewystąpienia interesującej nas konieczności jest napływ penitentów na dużą uroczystość, albo pielgrzymkę. W takiej bowiem sytuacji, powinni wcześniej we własnej parafii skorzystać ze spowiedzi indywidualnej.

Prawdopodobnie w sytuacji nadużywania w niektórych krajach prawa do udzielania rozgrzeszenia zbiorowego, papież Jan Paweł II wydał w 2002 roku Motu proprio Misericordia Dei, w którym dokładniej sprecyzował przypadki uznawane za wystąpienie poważnej konieczności. W dokumencie tym czytamy: odnośnie do przypadku „poważnej konieczności” uściśla się co następuje - chodzi o sytuacje obiektywnie wyjątkowe, mogące mieć miejsce na terenach misyjnych, czy w odizolowanych wspólnotach wiernych, do których kapłan może dotrzeć jedynie raz lub kilka razy w roku, ponadto warunki wojenne, meteorologiczne, albo tym podobne okoliczności ${ }^{43}$. Należy

\footnotetext{
${ }^{42}$ Kan. 961.

${ }^{43}$ Jan PaWeŁ II, Motu proprio Misericordia Dei, 7.04.2002, Poznań 2002, s. 11.
} 
podkreślić, że nie chodzi tutaj o znalezienie się penitentów w jakimkolwiek niebezpieczeństwie śmierci, nawet podczas wojny czy poważnej klęski żywiołowej. Wystarcza ich obecność na terytorium objętym wojną, klęską, lub izolacją.

Ocena, czy zostały spełnione wymagane przez prawo warunki, w tym czy zaszła poważna konieczność, należy najpierw do biskupa diecezjalnego terytorium udzielania absolucji generalnej. Posiada on możliwość (choć nie jest to jego obowiązek), wydania prawa diecezjalnego, odnoszącego się do omawianej kwestii. W przypadku, kiedy zdecyduje się na prawne sprecyzowanie terminu „poważna konieczność", musi, jak podaje norma kodeksowa, wziąć pod uwagę kryteria wypracowane przez Konferencję Biskupów, której jest członkiem. Manzanares uważa ponadto, iż może on ważnie i godziwie zezwalać na udzielanie zbiorowego rozgrzeszenia, mimo, iż tego nie przewidują kryteria ustalone przez wspomnianą Konferencję. Jest bowiem głównym szafarzem tajemnic Bożych, kierownikiem, krzewicielem i stróżem całego życia liturgicznego, kierownikiem karności pokutnej w powierzonym sobie Kościele. Posiada władzę zwyczajną, własną i bezpośrednią, potrzebną do spełniania swojego pasterskiego urzędu ${ }^{44}$.

Czy prezbiter jest kompetentny do oceny czy zachodzi poważna konieczność. Według Pastuszki, zarówno w prawie przedkodeksowym, jak i w kodeksie z 1983 r. został takiej możliwości pozbawiony ${ }^{45}$. Zasadniczo można się z tym zgodzić. Jednak czasami sam spowiednik, który wraz z penitentami znalazł się w konkretnych okolicznościach, może być niejako zmuszony do podjęcia decyzji. Jak się wydaje, ze względu na naczelną zasadę prawną - salus animarum suprema lex, ma on również możliwość oceny i decyzji o udzieleniu omawianego rozgrzeszenia w przypadku, kiedy konferencja Biskupów nie ustaliła wspomnianych kryteriów i nie może skontaktować się z biskupem

\footnotetext{
${ }^{44}$ J. Manzanares, De absolutione generali in casu gravis necessitatis considerationes, Periodica 76(1987) fasc. 1, s. 133.

${ }^{45}$ M. Pastuszko, Sakrament pokuty i pojednania, Kielce 1999, s. 122.
} 
diecezjalnym, posiadającym prawo do decydowania w takich nadzwyczajnych okolicznościach.

Kolejna norma odnosząca się do sakramentu pokuty zawierająca warunek konieczności obowiązku spowiadania. Każdy duszpasterz ma obowiązek troski, aby powierzeni mu wierni mogli się wyspowiadać, jeżeli proszą o to w sposób uzasadniony, w dogodnych dla nich dniach i godzinach. Natomiast przy wystąpieniu nagłej konieczności taki obowiązek spoczywa na wszystkich spowiednikach ${ }^{46}$. Spowiednik nie musi być duszpasterzem, to każdy kapłan posiadający upoważnienie do spowiadania (np. pracownik kurii, pracownik naukowy, emeryt).

Przepis mówi o nagłej konieczności. Występuje ona wtedy, gdy wierny powinien się wyspowiadać, a nie może tego uczynić w czasie wyznaczonym na sprawowanie sakramentu w świątyni. Pighin za takie okoliczności uznaje przykładowo wigilię przed zawarciem sakramentalnego małżeństwa, przyjęciem chrztu, czy Świąt Wielkanocnych (i ile oczywiście w tym czasie zwykle nie sprawuje się pokuty i pojednania) ${ }^{47}$. Frank natomiast zauważa, iż kanon nie wspomina o konieczności, ale o nagłej konieczności, co oznacza, ze wierni zasadniczo powinni się spowiadać w dniach i czasie wyznaczonym, a duszpasterze przestrzegać obowiązku spowiadania w określonych przez siebie porach dnia ${ }^{48}$. Użycie przez prawodawcę słowa „nagła” wydaje się wskazywać na konieczność wyspowiadania się, której wcześniej nie dało się przewidzieć. I tak przykładowo, penitent powinien przyjąć Eucharystię przy okazji chrztu, bierzmowania, pierwszej Komunii swojego dziecka, pogrzebu bliskiej osoby, a niedawno popełnił grzech, który mu to uniemożliwia. Do tego również nie ma możliwości przystąpienia do spowiedzi w wyznaczonym w którejś w najbliższych świątyń czasie. W takich właśnie okolicznościach możemy mówić o konieczności nagłej.

\footnotetext{
${ }^{46}$ Kan. 986.

${ }^{47}$ B. F. Pighin, dz. cyt., s. 281.

${ }^{48}$ E. Frank, dz. cyt., s. 178.
} 
Drugim sakramentem uzdrowienia jest namaszczenie chorych. Do konieczności odwołuje się ustawodawca kościelny w kontekście możliwości poświęcenia przez prezbitera oleju używanego do namaszczenia chorych, o ile właśnie powinien udzielić sakramentu. W innych okolicznościach, poświęcenia dokonuje biskup oraz prezbiterzy prawnie zrównani $z$ biskupem diecezjalnym ${ }^{49}$. Prawodawca nie określa natury ani stopnia takowej konieczności, dlatego szafarz sam ocenia konkretną sytuację, mając na uwadze, że ma to być vera necessitatis. Stanu tego nie można ograniczać jedynie do niebezpieczeństwa śmierci, taka zawężona interpretacja byłaby bowiem niezgodna z zamysłem prawodawcy i nie odpowiadała współczesnym realiom duszpasterskim. Ponadto sprzeciwiałaby się normie kodeksowej ${ }^{50}$ zezwalającej na powtórne namaszczenie ${ }^{51}$.

Przypadek konieczności weryfikuje się w dwóch przypadkach. Ze względu na odległość, kiedy prezbiter nie może otrzymać od własnego biskupa, oleju poświęconego. Po drugie, gdy w konkretnym przypadku pojawiła się konieczność udzielenia sakramentu namaszczenia chorych i prezbiter poświęca olej podczas ceremonii liturgicznej ${ }^{52}$.

Czy brak spełnienia przesłanki konieczności skutkuje nieważnością poświęcenia oleju przez prezbitera, no i co za tym idzie również nieważnością sprawowania sakramentu? Wydaje się że tak nie jest. Zastrzeżenie biskupowi dokonywania czynności poświęcenia wiąże się zapewne $z$ uwypukleniem faktu, iż to on jest pierwszym szafarzem sakramentów w swojej diecezji, a skoro biskupi od epoki średniowiecza praktycznie bardzo rzadko udzielają omawianego sakramentu, to gest poświęcenia łączy ich niejako z poddanymi ich opiece duszpasterskiej chorymi, namaszczanymi przez prezbiterów. Ponadto prezbiterzy $\mathrm{w}$ przewidzianych przez prawo powszechne

\footnotetext{
${ }^{49}$ Kan. 999.

${ }^{50}$ Kan. 1004 par. 2.

${ }^{51}$ B. W. Zubert, Sakrament namaszczenia chorych, w: Komentarz do Kodeksu prawa kanonicznego. Księga IV. Uświęcające zadanie Kościoła, t. III/2, Poznań 2011, s. $188-189$.

${ }^{52}$ E. Frank, dz. cyt., s. 194.
} 
przypadkach, również są szafarzami interesującego nas poświęcenia. I w końcu, Kościół nie może automatycznie pozbawiać sakramentu, w pewnych okolicznościach zapewniającego wiernemu życie wieczne, jakiejkolwiek osoby, dlatego, że prezbiter dokonał bezprawnego poświęcenia oleju. Chociaż takie jego działanie jest z pewnością bezprawne i moralnie niegodziwe.

Zgodnie z księgą obrzędów omawianego sakramentu, namaszcza się głowę i ręce osoby chorej lub w podeszłym wieku ${ }^{53}$. Norma kodeksowa zezwala jednak, aby w przypadku konieczności, namaścić tylko jedną część ciała, na przykład czoło ${ }^{54}$. Konieczność, jak zauważa Zubert, może być spowodowana różnymi okolicznościami, takimi jak: bliskie niebezpieczeństwo śmierci, fizyczna przeszkoda utrudniająca namaszczenie rąk lub czoła, duża liczba chorych, którym udziela się sakramentu, przy jednoczesnym braku czasu na zachowanie całego przewidzianego obrzędu, itp ${ }^{55}$. Można tutaj nadmienić częsty przypadek, występujący podczas katastrofy pojazdu samochodowego lub budynku - ciało rannego zostało przygniecione i udaje się dotrzeć do jego innej części, niż przewidziana w obrzędzie.

Decyzję dotyczącą zastosowania namaszczenia w przypadku konieczności podejmuje szafarz sakramentu.

Norma kodeksowa zezwala kapłanom na noszenie ze sobą poświęconego oleju, aby w razie konieczności mogli udzielić interesującego nas sakramentu ${ }^{56}$. Ma ona na celu umożliwić każdemu kapłanowi udzielenie sakramentalnego namaszczenia w sytuacjach niecierpiących zwłoki ${ }^{57}$. Przypadkiem konieczności będzie tutaj każda sytuacja, w której kapłan uzna, że w odniesieniu do napotkanej osoby, powinien on sprawować sakrament namaszczenia.

\footnotetext{
${ }^{53}$ Rituale Romanum, ex Decreto Sacrosancti Oecumenii Concilii Vaticani II instauratum, Auctoritate Pauli PP. VI promulgatum, Ordo Unctionis Infirmorum eorumque Pastoralis Curae, Editio typica. Typis Polyglottis Vaticanis 1972, nr 23.

${ }^{54}$ Kan. 1000 par. 1.

${ }^{55}$ B. W. ZubErT, dz. cyt., s. 190.

${ }^{56}$ Kan. 1003 par. 3.

${ }^{57}$ B. W. Zubert, dz. cyt., s. 198.
} 


\section{Necessitas jako kategoria kanoniczna - synteza problemu}

$\mathrm{W}$ ostatnim punkcie opracowania zajmiemy się syntetycznym ukazaniem problemu kanonicznej kategorii konieczności, w odniesieniu do wcześniej rozpatrywanych sakramentów. Pierwszą interesującą nas kwestią będzie zestawienie rodzajów necessitatis, z jakimi spotkaliśmy się przy okazji analizy kodeksowego prawa o sakramentach. Dalej zostaną zebrane przypadki mieszczące się w omawianym pojęciu oraz przypomniane podmioty, decydujące o pojawieniu się przesłanek decydujących o zaistnieniu konieczności. Na zakończenie punktu piątego postaramy się o wypracowanie prawnej definicji necessitatis jako kategorii kanonicznej występującej w prawie o sakramentach.

Zacznijmy więc od rodzajów konieczności. Kodeks prawa kanonicznego papieża Jana Pawła II, w interesującej nas partii materiału wyróżnia następujące jej rodzaje:

- konieczność (którą można nazwać zwyczajną),

- konieczność duszpasterska,

- prawdziwa konieczność,

- nagła konieczność,

- poważna konieczność,

- ostateczna konieczność.

Z pierwszą z nich spotykamy się w najczęściej. Dotyczy między innymi przyjęcia Eucharystii, pokuty i namaszczenia chorych od szafarzy niekatolickich, zanoszenia Wiatyku przez jakiegokolwiek kapłana, lub szafarza Komunii św., udzielania chrztu w domach prywatnych oraz namaszczenia przez szafarza tylko jednej części ciała osoby przyjmującej sakrament chorych. Jakie sytuacje uzasadniają uznanie konkretnego przypadku za pojawienie się zwyczajnej konieczności? Są to między innymi niebezpieczeństwo śmierci po stronie pragnącego przyjąć sakrament, jego choroba, albo pozostanie przez dłuższy czas bez sakramentu. Przyczyną ich wystąpienia mogą być okoliczności nadzwyczajne, jak wojny, utrudnienia $\mathrm{z}$ dotarciem duszpasterza do wiernych z powodu dużych odległości, a ponadto brak możliwości sprawowania sakramentu przez szafarza z powodu jego stanu zdrowia, nieobecności, albo dużej liczby wiernych proszących o łaskę sakramentalną. 
Decyzję, czy wystąpiła konieczność prawo pozostawia biskupowi diecezjalnemu, szafarzowi sakramentu, a w jednym przypadku wiernemu (przyjmującemu sakrament od szafarza niekatolickiego).

Konieczność, z dodatkowym określeniem „duszpasterska”, dotyczy możliwości trynacji Mszy św. oraz przechowywania Eucharystii poza miejscem świętym i zabierania Jej w drogę. W pierwszym przypadku przesłankami do uznania, że takowa konieczność wystąpiła są brak kapłana niepotrzebującego trynować i umożliwienie większej liczbie wiernych w uczestniczeniu w niedzielnej albo świątecznej Eucharystii. W drugim, zagrożenie profanacji Najświętszego Sakramentu, albo brak odpowiedniego miejsca świętego dla przechowywania Komunii św. z powodu zniszczenia, uszkodzenia, zalania budynku. Osobami oceniającymi wystąpienie konieczności duszpasterskiej są biskup diecezjalny i kapłan celebrujący Mszę św., albo opiekujący się Najświętszym Sakramentem.

Jaka jest różnica między koniecznością, a koniecznością duszpasterską? Obie uzasadniają motywy duszpasterskie. Porównując przypadki w których zachodzą, nie można za bardzo doszukać się specyfiki każdej z nich.

Jak to już zostało ukazane wcześniej, tylko jeden raz prawodawca kościelny używa terminu vera necessitas (prawdziwa, rzeczywista konieczność). Dotyczy to możliwości poświęcenia przez prezbitera oliwy do udzielenia namaszczenia chorych. Konkretny przypadek weryfikuje szafarz sakramentu, jeżeli nie ma możliwości udania się do biskupa po poświęcony olej ze względu na odległość, lub czas, będąc zmuszonym niezwłocznie sprawować sakrament. Ustawodawca jak się wydaje, użył tutaj terminu „prawdziwa”, „rzeczywista”, przede wszystkim dla podkreślenia, że w innych okolicznościach niż podczas wystąpienia konieczności, zgodnie z wielowiekową tradycją, poświęcenia powinien dokonywać jednak biskup osobiście.

Przymiotnik „nagła” konieczność znalazł się w interesującej nas partii prawa o sakramentach również tylko jeden raz. Dotyczy obowiązku sprawowania sakramentu pokuty przez wszystkich kapłanów, posiadających możliwość spowiadania, a więc specjalne upoważnienie do dokonywania takiego aktu. Pojawia się w sytuacji, której 
wcześniej raczej nie dało się przewidzieć i przyjąć sakrament od duszpasterza w przeznaczonym do tego czasie, w okolicznościach $\mathrm{w}$ pewnym sensie niezależnych od penitenta.

Bardziej restrykcyjnym terminem jest „poważna konieczność”. Dotyczy udzielania sakramentów chrześcijanom nienależącym do Kościoła katolickiego oraz rozgrzeszenia zbiorowego bez uprzedniej spowiedzi indywidualnej. Przesłanką weryfikującą jej wystąpienie może być choroba wiernego, trudność moralna w przyjęciu sakramentu od własnego szafarza, sytuacje nadzwyczajne, takie jak pozbawienie wolności, ucieczka z własnego kraju, klęska żywiołowa, warunki misyjne, pozostawanie przez długi czas bez łaski sakramentalnej. Ocena, a nawet sprecyzowanie warunku poważnej konieczności należy do Konferencji Biskupów, biskupa diecezjalnego, albo szafarza sakramentu. Jak w tym przypadku łatwo można zauważyć, termin „poważna” konieczność odnosi się zatem do wyjątkowo nadzwyczajnych sytuacji życiowych, w których mogą się znaleźć jakieś grupy osób pragnących przystąpić do sakramentów.

Ostatnim $\mathrm{z}$ interesujących nas, a używanych przez prawodawcę kościelnego terminem jest „ostateczna konieczność”. Występuje on jednokrotnie i odnosi się do konsekracji postaci Eucharystycznych. Norma kodeksowa ustanawiając zakaz konsekracji chleba i wina poza Mszą św., albo jednej postaci podczas Mszy i podkreśla, że będzie to niegodziwe nawet w ostatecznej konieczności. Widać zatem wyraźnie, że termin „ostateczna” ma za zadanie wyszczególnienie i uwypuklenie zakazu wspomnianego postępowania nawet, jeżeli wydaje się, że nie można działać inaczej a wierni zostaną pozbawieni Eucharystii. Kategoria ostatecznej konieczności stoi w tym przypadku niejako na straży godziwego celebrowania Eucharystii oraz wyrażenia dla Niej najwyższego szacunku. Wartości te stawiane są w przewidzianych przez prawo przypadkach na wyższym szczeblu, niż ewentualna szkoda duchowa po stronie wiernego.

Na zakończenie dywagacji należy zauważyć, że w omawianej części Kodeksu prawa kanonicznego termin „konieczność” wiąże się z konsekwencją bezprawnego, moralnie niegodziwego działania, podczas sprawowania sakramentu w okolicznościach niespełniających 
kryteriów dla warunków go determinujących. W przeciwieństwie do kategorii - „potrzeba duszpasterska”, łączy się zasadniczo z sytuacjami, w których odstąpienie od sprawowania sakramentu spowoduje poważną szkodę duchową u wiernego.

Czym zatem jest interesująca nas kategoria kanoniczna i w jaki sposób może być definiowana? Necessitas to termin występujący w Kodeksie prawa kanonicznego, z którym, najwyższy prawodawca kościelny wiąże wystąpienie pewnych szczególnych okoliczności, zezwalających na podjęcie działania, zmierzającego do godziwego sprawowania konkretnego sakramentu. Okoliczności te są uzależnione od stopnia konieczności, im jest on bardziej rygorystyczny, tym okoliczności muszą być poważniejsze.

\section{Zakończenie}

Sakramenty ustanowione dla swoich wyznawców przez Chrystusa, udzielają osobom je przyjmującym łaski, którą oznaczają. Są skuteczne, bo działa w nich sam Jezus. Stanowią również celebrację tajemnicy, misterium Bożego we wspólnocie Kościoła. Przedmiotem badań, których rezultaty zostały opublikowane w powyższym artykule, były sakramenty chrztu bierzmowania, Eucharystii, pokuty i namaszczenia chorych w aspekcie ich sprawowania, uwzględniającym warunek wystąpienia konieczności. Konieczność bowiem, należy do kategorii kanonicznych, spotykanych w Kodeksie prawa kanonicznego papieża Jana Pawła II.

Kodeks wyróżnia następujące jej rodzaje: necessitas (którą można nazwać zwyczajną), konieczność duszpasterska, prawdziwa konieczność, nagła konieczność, poważna konieczność, ostateczna konieczność. Pierwszą z wymienionych odnajdujemy w omawianym dokumencie najczęściej. Sytuacje ją warunkujące to między innymi niebezpieczeństwo śmierci po stronie pragnącego przyjąć sakrament, jego choroba, albo pozostanie przez dłuższy czas bez sakramentu. Przyczyną wystąpienia konieczności bywają okoliczności nadzwyczajne, jak wojny, utrudnienia $z$ dotarciem duszpasterza do wiernych z powodu dużych odległości, a ponadto brak możliwości sprawowania sakramentu przez szafarza z powodu jego 
stanu zdrowia, nieobecności, albo dużej liczby wiernych proszących o łaskę sakramentalną.

Najbardziej „ostrymi” kategoriami spośród omówionych są „poważna konieczność” i „ostateczna konieczność”. Pierwsza z nich odnosi się do sytuacji związanych z chorobą wiernego, trudnością moralną w przyjęciu sakramentu od własnego szafarza, sytuacjami nadzwyczajnymi, takimi jak pozbawienie wolności, ucieczka z własnego kraju, klęska żywiołowa, warunki misyjne, pozostawanie przez długi czas bez łaski sakramentalnej. Ocena, a nawet sprecyzowanie warunku poważnej konieczności należy do Konferencji Biskupów, biskupa diecezjalnego, albo szafarza sakramentu.

Kategoria zawarta w terminie „konieczność ostateczna”, ma niejako za zadanie wyszczególnienie i uwypuklenie wśród innych norm prawnych, zakazu konsekracji chleba i wina poza Mszą św. oraz tylko jednej z wymienionych postaci eucharystycznej podczas Mszy, stojąc na straży godziwego celebrowania Wieczerzy Pańskiej i najwyższego szacunku dla Chrystusa ukrytego w Eucharystii.

Można zatem przyjąć następującą definicję necessitas: „konieczność" to termin występujący w Kodeksie prawa kanonicznego, z którym, najwyższy prawodawca kościelny wiąże wystąpienie pewnych szczególnych okoliczności, zezwalających na podjęcie działania, zmierzającego do godziwego sprawowania konkretnego sakramentu.

\section{Canonical category „necessity” on the sacramental law in the Code of 1993 year}

In the Code of Canon Law in the part about sacraments baptism, confirmation, Eucharist, penance and anointing of the sick there are canonical category "necessity". This designation has five kinds: necessity (regular), vera necessity, pastoral necessity, grave necessity, extreme necessity. In this article are analyses canonical norms inclusive those categories. Text shows a conditions since depend necessity also, for example illness, war, earthquake. On the end of article is definition of canonical category necessitas.

SŁowA KluCzowE: prawo kanoniczne, sakramenty, chrzest, bierzmowanie Eucharystia, pokuta, namaszczenie chorych, konieczność, kategoria kanoniczna 
KeY Words: canon law, sacraments, baptism, confirmation, Eucharist, penance, anointing of the sick, necessity, canonical category

\section{Nota o Autorze:}

KS. PROF. ZW. DR HAB. ZBIGNIEW JANCZEWSKI - pracownik naukowo-dydaktyczny na Wydziale Prawa Kanonicznego Uniwersytetu Kardynała Stefana Wyszyńskiego w Warszawie, kierownik Katedry prawa o posłudze uświęcania, członek Stowarzyszenia Kanonistów Polskich i Consociatio Internationalis Studio Iuris Canonici Promovendo, autor licznych prac z zakresu kanonicznego prawa o posłudze uświęcania. 